УДК 358.1

Адаменко М. В ${ }^{1}$;

Ільяшов О.А. д.військ.н., с.н.с. ${ }^{2}$

${ }^{1}$ - Кафедра ракетних військ i артилерії командно-штабного інституту застосування військ (сил) Національного університету оборони України ім. Івана Черняховського, Київ;

2 - Науково-дослідний інститут Головного управління розвідки Міністерства оборони України, Київ

\title{
Оцінювання оперативності функціонування системи артилерійської розвідки в інтересах вогневого ураження противника ракетними військами і артилерісю
}

Резюме. Стаття присвячена обгрунтуванню можливості використання підходів теорії масового обслуговування, як альтернативи методу нормативного оцінювання оперативності, який використовується при оцінюванні оперативності функціонування системи артилерійської розвідки в інтересах вогневого ураження противника ракетними військами і артилерією. Обгрунтована перевага об'єднання каналів отримання та обробки розвідувальної інформації в єдину систему, та розроблена методика оцінювання оперативності функціонування системи артилерійської розвідки в інтересах вогневого ураження противника ракетними військами і артилерією

Ключові слова: оперативність, функціонування системи артилерійської розвідки, вогневе ураження противника ракетними військами i артилерією, система масового обслуговування, потік заявок, інтенсивність надходження заявок на отримання розвідувальних даних.

Постановка проблеми. В сучасних умовах вогневе ураження набуває особливого значення в розгромі противника і досягненні визначених цілей ведення бойових дій. Враховуючи те, що в сучасних збройних конфліктах зменшується частка завдань із використанням зброї масового ураження тому частка завдань, що покладається на звичайні засоби вогневого ураження значно зростає. В той же час ефективність вогневого ураження залежить від ряду чинників. Одним 3 таких чинників є умови в яких ведуться бойові дії [1-4]. На думку військових фахівців провідних країн світу неврахування умов ведення бойових дій може привести до зниження бойового потенціалу військових формувань на 20...30 \% [5]. Звичайно для зменшення негативного впливу умов на вогневе ураження ïх необхідно враховувати як під час планування, так і під час ведення бойових дій. До того ж ефективність функціонування системи артилерійської розвідки напряму залежить від своєчасності (оперативності) отримання необхідної розвідувальної інформації. Швидка зміна обстановки, яка притаманна сучасним збройним конфліктам вимагає зменшення часу на підготовку даних для проведення вогневого ураження противника - відповідно зменшується час потрібний на функціонування системи артилерійської розвідки.

Водночас процес "виявлення-ураження" об’єктів противника ракетними військами i артилерією передбачає ще й певну точність розвідувальних даних.

Таким чином, у підвищенні оперативності виникає протиріччя між потребою 3 одного боку зменшення обсягу та тривалості необхідних розрахунків, а 3 іншого збільшення цих характеристик для максимізації ïх точності. Виходячи 3 цього, виникає необхідність у такому науково-методичному апараті, який би дозволяв усунути таке протиріччя.

Ступінь розробленості проблеми. Аналіз останніх досліджень і публікацій [6-9] 3 наведених питань показує, що на даний час при оцінці оперативності функціонування системи артилерійської розвідки (далі оперативності) приймають, що вона залежить від характеристик джерел розвідувальної інформації, які застосовуються для цього. Показниками оперативності в даному випадку $є$ час розгортання розвідувальних засобів на позиції та підготовки до розвідки, час на один цикл виконання розвідувального завдання та час передачі розвідданих до зацікавлених інстанцій. Величини даних показників обумовлені тактико-технічними характеристиками розвідувальних засобів, засобів зв'язку; підготовкою обслуговуючого персоналу i дорівнюють: час розгортання розвідувального засобу на позиції, час одного циклу виконання розвідувального завдання; час передачі розвідданих до споживачів під час ведення бойових дій. 


\section{ВОЄННО-ПРИКЛАДНІ ПИТАННЯ МАТЕМАТИЧНОГО АНАЛІЗУ ТА МАТЕМАТИЧНОГО МОДЕЛЮВАННЯ}

Наведені показники носять нормативний характер i не дозволяють передбачити врахування умов конкретної обстановки під час отримання та обробки розвідувальних відомостей.

У той же час, аналіз результатів досліджень [1,7] показує, що розвідувальні засоби під час забезпечення бойового застосування PBiA розосереджуються за часом та простором, їм притаманні цикли робіт випадкової тривалості, що багаторазово повторюються. Приведені особливості дають можливість розглянути систему артилерійської розвідки, як систему масового обслуговування [10-15].

Аналізуючи досвід застосування методів теорії масового обслуговування в різних галузях як науки, так і практики [1015] можна визначити переваги даних методів у порівнянні 3 методом нормативної оцінки оперативності функціонування системи артилерійської розвідки, який використовують на даний момент. Це можливість оцінити оперативність в кожній ситуації відповідно до задач, які були виконанні, можливість застосувати показник оперативності до сукупності розвідувальних засобів, як до системи масового обслуговування.

Водночас, невирішеною раніше частиною загальної проблеми усунення протиріччя $\epsilon$ відсутність такої методики оцінювання оперативності, яка б на відміну від існуючої передбачала врахування особливостей функціонування системи артилерійської розвідки в інтересах вогневого ураження ракетними військами і артилерією. До таких особливостей можна віднести високу динаміку бою (операції), розподіл артилерії за принципами "рота-батарея" та “виявлення-ураження", обмеження застосування ракет, реактивних систем залпового вогню та далекобійної артилерії $[1,4]$.

Беручи до уваги переваги методів теорії масового обслуговування та особливостей функціонування системи артилерійської розвідки в інтересах вогневого ураження ракетними військами і артилерією, вважається за доцільне розглянути можливість застосування методів теорії масового обслуговування при розробці методики оцінювання оперативності функціонування системи артилерійської розвідки в інтересах вогневого ураження ракетними військами i артилерією.
Метою статті $€$ обгрунтування можливості використання методів теорії масового обслуговування для оцінювання оперативності та розробка методики оцінювання оперативності функціонування системи артилерійської розвідки.

Виклад основного матеріалу. В загальному вигляді функціонування системи артилерійської розвідки в інтересах вогневого ураження противника ракетними військами i артилерією розглядається, як система масового обслуговування, що складається із наступних елементів: вхідного потоку заявок на розвідувальні данні, каналів обробки заявок, черги заявок на розвідувальні данні, що чекають обслуговування i вихідного потоку заявок на розвідувальні данні. Для подальшого дослідження приймається, що в системі $є n$ каналів обробки заявок (розвідувальних засобів), на канали обробок заявок надходить потік заявок на отримання розвідувальних даних. Вважається що це - найпростіший стаціонарний пуассоновський потік 3 інтенсивністю $\lambda$. Також допускається, що час обслуговування однієї заявки одним розвідувальним засобом розподілено по показовому закону з параметром $\mu$ [10-12]. При розгляді розвідувальних засобів, які працюють в одній системі, відповідно, всі заявки замикаються на загальну систему. Сумарний потік заявок як відомо, також є найпростішим пуассоновським, 3 інтенсивністю $\lambda_{i}=\ddot{i} \lambda$. Таким чином можливо вважати, що сумарна кількість каналів обслуговування (розвідувальних засобів) дорівнює $N=\sum_{j=1}^{n} g_{j}$, де $g_{j}-$ кількість каналів обслуговування в одному розвідувальному засобі.

Розглядаючи інтенсивність обслуговування заявки необхідно врахувати, що канали обслуговування заявок (розвідувальні засоби), які застосовуються в ракетних військах i артилерії $є$ однотипними та мають однакові можливості щодо обробки розвідувальних відомостей. Виходячи 3 цього інтенсивність обслуговування на кожному із каналів $N$ не змінюється і рівна $\mu$. Таким чином, система артилерійської розвідки являє собою СМО типу M/M/N 3 навантаженням рівним:

$$
\rho_{n}=n \lambda / \mu=n \rho
$$

Для спрощення розрахунків та підвищення розуміння фізичного смислу пропонується основною характеристикою оперативності прийняти повний час перебування заявки в системі, який враховує 
час очікування в черзі $\left(T_{\text {оч }}\right)$ та час

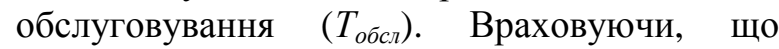
прийнята до обробки заявка обробляється лише одним каналом і не може бути передана на доопрацювання на інший канал, середній час обслуговування для різних варіантів обслуговування рівний [11] $T_{\text {обсл }}=1 / \mu$

В той же час, враховуючи постійну змінність бойової обстановки, приймається, що значення часу очікування для кожної заявки буде різним, тобто, для спрощення розрахунків в межах необхідної їх точності можна стверджувати, що $n=1, j=1$ (тобто $N=n)$. Тоді, загальний вираз для визначення часу очікування у системі M/M/n пропонується подати у вигляді: $T_{o \psi, \mathrm{n}}=M_{n} / \lambda_{n}$,

де $M_{n}$ - математичне очікування кількості заявок в черзі.

Систему артилерійської розвідки можливо охарактеризувати наступними особливостями: система складається із обмеженої кількості каналів, кожен канал може одночасно обробити тільки одну заявку, кожна нова надіслана заявка, заставши всі канали зайняті, стає в чергу і знаходиться в ній до тих пір доки один із каналів не звільниться. Якщо заявка надходить в систему, коли є вільний канал, вона відразу приймається до обробки, тому математичне очікування кількості заявок в черзі або, іншими словами, середня довжина черги буде визначатися як для системи 3 необмеженим потоком заявок, а саме:

$$
M_{n}=\frac{\rho_{n} P_{n}}{n\left(1-\rho_{n} / n\right)^{2}}
$$

де $P_{n}-$ імовірність того, що зайнято обслуговуванням $n$ каналів і визначається за формулою:

$$
P_{n}=\frac{\rho_{n}^{n}}{n !} P_{0}
$$

де $P_{0}$ - імовірність вільного стану системи для даного типу СMO i визначається за формулою:

$$
P_{0}=\left[\sum_{i=0}^{n} \frac{\rho_{n}^{i}}{i !}+\frac{\rho_{n}^{n+1}}{n !\left(n-\rho_{n}\right)}\right]^{-1}
$$

Загальна формула $M_{n}$ після підстановки $P_{0}$ та $P_{n}$ приймає вигляд:

$$
M_{n}=\frac{\rho_{n}^{n+1}}{n ! n\left(1-\rho_{n} / n\right)^{2}}\left[\sum_{i=0}^{n} \frac{\rho_{n}^{i}}{i !}+\frac{\rho_{n}^{n+1}}{n !\left(n-\rho_{n}\right)}\right]^{-1}
$$

Отже вираз для визначення часу очікування у вибраній системі, враховуючи загальний вираз та підставляючи математичне очікування кількості заявок в черзі, пропонується подати у вигляді:

$$
T_{\text {ou,n }}=\frac{\rho}{n \mu(1-\rho)\left[\left(1-\rho^{2}\right) \Delta_{n}+\rho^{2}\right]}
$$

де $\Delta_{n}=P_{l} / P_{n}-$ коефіцієнт співвідношення відмови в негайному початку обслуговування через зайнятість каналів.

Виходячи $3[10,11]$, значення $P_{1}$ та $P_{n}$ пропонується обчислювати за формулою Ерланга, при цьому, величини $\Delta_{n}$ для деяких значень $\rho$ та $\mathrm{n}$ наведені в Табл. 1. - залежність величини коефіцієнту співвідношення відмови в негайному початку обслуговування через зайнятість каналів $\left(\Delta_{n}\right)$ від кількості каналів $(n)$ та величини навантаження на СМO $(\rho)$

$$
P_{n}=\left\{\begin{array}{c}
\frac{\rho}{1+\rho}, \quad n=1 \\
\frac{\rho_{n}^{n}}{n !}\left[\sum_{i=0}^{n} \frac{\rho_{n}^{i}}{i !}\right]^{-1}, n>1
\end{array}\right.
$$

Таблиця 1

\begin{tabular}{|l|l|l|l|l|}
\hline \multirow{2}{*}{$\mathrm{n}$} & \multicolumn{4}{|l|}{ Значення $\Delta_{n}$ при $\rho$} \\
\cline { 2 - 5 } & 0,2 & 0,4 & 0,6 & 0,8 \\
\hline 2 & 3,08 & 1,89 & 1,52 & 1,35 \\
\hline 3 & 8,41 & 3,18 & 2,08 & 1,66 \\
\hline 4 & 21,70 & 5,06 & 2,70 & 1,95 \\
\hline 5 & 54,33 & 7,79 & 3,41 & 2,23 \\
\hline 10 & 4510 & 54,84 & 8,77 & 3,67 \\
\hline
\end{tabular}

Опосередкування даних (Табл. 1), окрім екстремальних величин першого стовпчика та останньої строки, дає кількісну характеристику тенденції зростання оперативності функціонування при збільшені ступеня централізації системи: в середньому ефективність зростає в 2,9 рази. Величини наведені в (Табл. 1) показують перевагу функціонування системи артилерійської розвідки перед функціонуванням системою, яка складається 3 одного розвідувального засобу, оскільки показують у скільки раз зменшується ймовірність відмови в негайному обслуговуванні або - у скільки раз зростає імовірність того, що заявка на отримання розвідувальних даних буде прийнята до негайного обслуговування. Виходячи 3 [11, 13], та враховуючи тип СМО повний час перебування заявки в системі пропонується визначати як залежність $T_{n}=T_{o q, \mathrm{n}}+1 / \mu$.

В той же час можливо записати дану формулу як систему рівнянь, однією $з$ яких $\epsilon$ формула визначення часу перебування заявки в системі що складається із одного каналу $(n=1)$, іншим формула визначення часу перебування заявки в системі, що складається із $n$ каналів $(n>1)$. 


$$
T_{n}=T_{\text {oч }, n}+\frac{1}{\mu}=\left\{\begin{array}{c}
\frac{1}{\mu(1-\rho)}, n=1, \\
\frac{1}{\mu}\left[1+\frac{\rho}{n(1-\rho)\left[\left(1-\rho^{2}\right) \Delta_{n}+\rho^{2}\right]}\right], n>1
\end{array}\right.
$$

Для кількісного оцінювання переваги застосування системи артилерійської розвідки перед застосуванням окремих розвідувальних засобів приймається приріст оперативності за рахунок об'єднання в систему $(\delta)$, який по своїй суті $є$ співвідношенням часу перебування заявки в системі що складається із одного каналу $(n=1)$, до часу перебування заявки в системі, що складається із $\mathrm{n}$ каналу $(n>1)$ і виражається розрахунковою формулою:

$$
\delta=\frac{T_{1}}{T_{n}}=\left[1-\rho+\frac{\rho}{n} \frac{1}{\left(1-\rho^{2}\right) \Delta_{n}+\rho^{2}}\right]^{-1}
$$

Результати визначення значень $\delta$ при різноманітних комбінаціях величин $\rho$ та $n$ наведені в (Табл. 2 - залежність величини приросту оперативності за рахунок об'єднання в загальну систему $(\delta)$ від кількості каналів (n) та величини навантаження на СMO $(\rho))$.

Таблиця 2

\begin{tabular}{|c|c|c|c|c|c|c|}
\hline \multirow{2}{*}{$\mathrm{n}$} & \multicolumn{7}{|c|}{ Значення $\delta$ при $\rho$} \\
\cline { 2 - 7 } & $\rightarrow 0$ & 0,2 & 0,4 & 0,6 & 0,8 & $\rightarrow 1$ \\
\hline 1 & 1 & 1 & 1 & 1 & 1 & 1 \\
\hline 2 & 1 & 1,24 & 1,40 & 1,60 & 1,80 & 2 \\
\hline 3 & 1 & 1,25 & 1,55 & 1,93 & 2,41 & 3 \\
\hline 4 & 1 & 1,25 & 1,61 & 2,12 & 2,87 & 4 \\
\hline 5 & 1 & 1,25 & 1,63 & 2,24 & 3,22 & 5 \\
\hline 10 & 1 & 1,25 & 1,66 & 2,44 & 4,15 & 10 \\
\hline$\rightarrow \infty$ & 1 & 1,25 & 1,67 & 2,50 & 5 & $\rightarrow \infty$ \\
\hline
\end{tabular}

Обробка даних (Табл. 2) способом опосередкування (без урахування першого стовпчика та останньої строки), дає кількісну характеристику зростання оперативності функціонування при збільшені ступеня централізації системи. Також при збільшенні навантаження на систему артилерійської розвідки оперативність іi функціонування в середньому зростає в 1,9 рази. Величини наведені в (Табл. 2) показують перевагу системи артилерійської розвідки перед системою, яка складається 3 одного розвідувального засобу, оскільки показують у скільки разів збільшується оперативність функціонування системи артилерійської розвідки перед системою яка не пов'язує розвідувальні засоби в єдину систему.

Отже результати (Табл. 2) свідчать про те, що підрозділам ракетних військ і артилерії під час бойового застосування доведеться чекати забезпечення розвідувальними даними вдвічі менше часу.

Зважаючи на чутливість даного методу до суті процесу функціонування системи артилерійської розвідки в інтересах вогневого ураження противника ракетними військами i артилерією, а також простоту та наочність, доцільним було б розробити на його основі методику оцінювання оперативності. Для більш різнопланового оцінювання оперативності пропонується вибрати ряд часткових показників та на їx основі визначити узагальнений показник оперативності функціонування системи артилерійської розвідки в інтересах ракетних військ i артилерії. Відомо [1], що кожен із показників повинен мати однозначний i зрозумілий фізичний смисл, бути “критичним” та зручним для обчислення та характеризувати основні властивості системи. Враховуючи дані вимоги, частковими показниками обрані: час перебування заявки в системі $\left(T_{n}\right)$, приріст оперативності за рахунок об'єднання в єдину систему $(\delta)$.

Звичайно, сукупність часткових показників повинна характеризувати систему якомога повніше [16]. Але швидше за все оцінити оперативність лише за сукупністю часткових показників неможливо, оскільки кожен із часткових показників характеризує лише одну властивість системи. Тому необхідно визначити узагальнений показник оцінювання оперативності. В даному випадку узагальненим показником оцінювання оперативності системи пропонується прийняти ймовірність отримання необхідної розвідувальних даних до заданого часу $(P(t))$.

В загальному вигляді ймовірність отримання розвідувальних даних враховуючи те, що випадковий час, коли розвідувальні дані залишаються актуальними, розподіляється за експоненціальним законом та визначається залежністю:

$$
P(t)=1-e^{-\lambda t},
$$

де $t$ - час, що відраховується 3 моменту подання заявки на отримання розвідувальних даних.

Отже, ймовірність отримання розвідувальних даних в заданий термін буде визначена як система рівнянь: 


$$
P\left(T_{n}\right)=1-e^{-\lambda T_{n}}=\left\{\begin{array}{c}
1-e^{-\lambda\left[\frac{1}{\mu(1-\rho)}\right]}, \ddot{1} \text { ðѐ } \delta \leq 1 \\
1-e^{-\lambda\left[\frac{1}{\mu}\left[1+\frac{\rho}{n(1-\rho)\left[\left(1-\rho^{2}\right) \Delta_{n}+\rho^{2}\right]}\right]\right]}, \text { ï ðѐ } \delta>1
\end{array}\right.
$$

Дана система рівнянь залишається актуальною в тому випадку, коли справедлива умова: $T_{n} \leq T_{\text {зад }}$

де $T_{\text {зад }}$ - час, доки розвідувальні дані залишаються актуальними. Якщо дана умова не виконується, то ймовірність отримання розвідувальних даних в заданий термін буде дорівнювати нулю.

Отже, блок-схема загального алгоритму методики оцінювання оперативності має вигляд як показано на рис. 1.

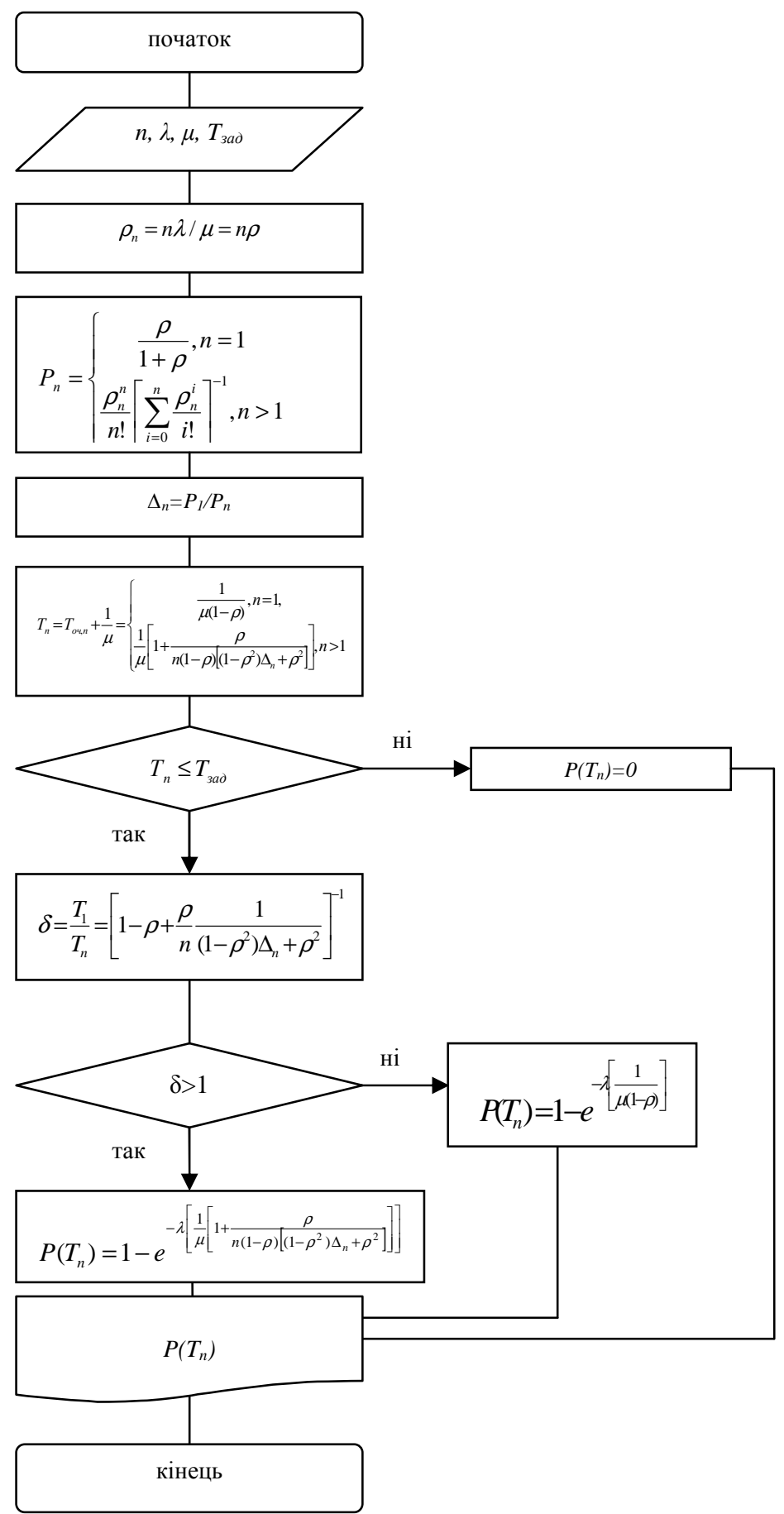

Рис. 1. Блок-схема загального алгоритму методики оцінювання оперативності 
Висновки. Таким чином, застосування загальної методики оцінювання оперативності функціонування системи артилерійської розвідки в інтересах вогневого ураження противника ракетними військами i артилерією, яка заснована на використанні методу теорії масового обслуговування забезпечує зменшення обсягу та тривалості необхідних розрахунків при максимізації їх точності, та на відміну від існуючої методики, яка грунтується на методі нормативної оцінки оперативності, передбачає додаткове врахування таких чинників: можливість функціонування системи артилерійської розвідки змінного складу; взаємозв'язок 3 умовами проведення конкретної операції (бою); проведення оцінювання оперативності за різними показниками;

можливість надання рекомендацій по кожній окремій ситуації.

Розрахунки показали, що використання методу теорії масового обслуговування під час оцінювання оперативності функціонування системи артилерійської розвідки в інтересах вогневого ураження ракетними військами і артилерією дозволить розробити рекомендації, за результатами впровадження яких буде можливо:

підвищити

оперативність функціонування системи артилерійської розвідки в середньому у 2 рази; оптимізувати ресурс сил та засобів системи артилерійської розвідки для кожної окремої ситуації;

підвищити гнучкість забезпечення розвідувальними даними вогневих підрозділів ракетних військ і артилерії.

\begin{tabular}{llr}
\multicolumn{2}{c}{ Подальші дослідження } & у даному \\
напрямку пропонується & присвятити \\
удосконаленню & методичного & апарату \\
отримання та обробки розвідувальних \\
відомостей для & забезпечення & вогневого \\
ураження ракетними військами і & артилерії та \\
оцінювання & ефективності & такого \\
забезпечення, обгрунтуванню оптимальної \\
кількості сил і засобів системи артилерійської \\
розвідки.
\end{tabular}

Подальші дослідження у даному удосконаленню методичного апарату отримання та обробки розвідувальних відомостей для забезпечення вогневого ураження ракетними військами і артилерії та оцінювання ефективності такого забезпечення, обгрунтуванню оптимальної розвідки.

\section{СПИСОК ВИКОРИСТАНОЇ ЛІТЕРАТУРИ}

1. Ракетні війська і артилерія. Досвід, реальність та перспективи. Монографія. - К.: НАОУ, 2007. - 227 c.

2. Каратуев М. Н., Дрещинский В. А. Особенности боевого применения артиллерии в локальных войнах и вооруженных конфликтах // Военная мысль. - 1996. - № 3. - С. 22-28.

3. Каратуев М. Н. Ракетные войска и артиллерия в локальных войнах и вооруженных конфликтах // Военная мысль. - 1998. - № 1. - С. 34-38.

4. Розвиток загальної тактики в локальних війнах $\mathrm{i}$ збройних конфліктах другої половини $\mathrm{XX}$ та початку XXI століть Монографія / Стрижевський В. В. - К.: НАОУ, 2006. - 272 с.

5. Репіло Ю. С. Погляди військових фахівців провідних країн світу на концепцію вогневого ураження противника в оперціях: Матеріали науково-практичного семінару кафедри РВіА. - К.: НУОУ, 12.03.2014. - С. 30-40.

6. Воробьёв А. С. Основы математического моделирования процессов функционирования сил и средств артиллерийской разведки. / Воробьёв А. С. - Л: ВАА, 1997. - 40 с.

7. Артиллерийская разведка. Ю.С. Федоров, А. Г. Павлов, Л. И. Головко и др. - М.: Воениздат, 1990. - 296 c.

8. Соленов Ю. А. Характер объектов разведки и поражения в составе наступающей группировки противника в начальный период войны. XXVI военно-научная конференция. - Л.: ВАА, 1998. C.156-157.

9. Стужук П. I. Теоретичні основи і практичні рекомендації щодо обробки розвідувальних відомостей (даних). - К.: НАОУ, 1998. - 80 с.

10. Вентцель Е. С. Исследование операций. - М.: Советское радио, 1972. - 516 с.

11. Вентцель Е. С. Теория вероятностей. - М.: Наука, 1969. $-416 \mathrm{c}$.

12. Вентцель Е. С. Исследование операций: задачи, принципы, методология. - М.: Наука, 1988. - 208 с.

13. Элементы теории массового обслуживания и асимптотического анализа систем. - К.: Вища школа, 1987. - 248 с.

14. Шуенкин В. А., Донченко В. С. Прикладные модели теории массового обслуживания. - К.: НМК ВО, 1992. - 308 с.

15. Новиков О. А., Петухов С. И. Прикладные вопросы теории массового обслуживания. - М.: Советское радио, 1969. - 398 с.

16. Барабаш Ю. Л. Основи теорії оцінювання ефективності складних систем: Навчальний посібник. - К.: НАОУ, 1999. - 38 с. 
Адаменко М. В. ${ }^{\text {; }}$;

Ільяшов А. А., Д.воен.н., с.н.с. ${ }^{2}$

${ }^{1}$ - Кафедра ракетных войск и артиллерии командно-штабного института применения войск (сил) Национального университета обороны Украины имени Ивана Черняховского, Киев

${ }^{2}$ - Научно-исследовательский институт Главного управления разведки Министерства обороны Украины, Киев

\section{Оценивание оперативности функционирования системы артиллерийской разведки в интересах огневого поражения противника ракетными войсками и артиллерией}

Резюме. Статья посвящена обоснованию возможности использования подходов теории массового обслуживания как альтернативы методу нормативного оценивания оперативности, который используется при оценивании оперативности функционирования системы артиллерийской разведки в интересах огневого поражения противника ракетными войсками и артиллериею. Так же в данной статье обосновано преимущество объединения каналов получения и обработки разведывательной информации в единую систему та разработана методика оценивания оперативности функционирования системы артиллерийской разведки в интересах огневого поражения противника ракетными войсками и артиллериею.

Ключевые слова: оперативность, функционирования системы артиллерийской разведки, огневого поражения противника ракетными войсками и артиллериею, система массового обслуживания, поток заявок, интенсивность поступления заявок на получения разведывательных данных.

M. Adamenko ${ }^{1}$;

O. Ilyashov, Ds.M, assistant professor ${ }^{2}$

${ }^{1}$ - The Department of Missile Forces and Artillery of the Command and Staff Institute for the Use of Troops (Forces) of the National Defence University of Ukraine named after Ivan Chernyhovsky, Kyiv;

${ }^{2}$ - Research Institute of the Main Intelligence Directorate of the Ministry of Defense of Ukraine, Kiev

Estimation of the operational efficiency of the artillery reconnaissance system in the interests of the enemy's fire destruction by missile forces and artillery

Resume. The article is devoted to the substantiation of the possibility of using the approaches of queuing theory as an alternative to the method of normative estimation of efficiency, which is used in assessing the operational efficiency of the artillery reconnaissance system in the interests of the enemy's fire destruction by missile forces and artillery. Also in this article, the advantage of combining the channels for obtaining and processing intelligence information in a single system is substantiated, and a methodology for assessing the operational efficiency of the artillery reconnaissance system in the interests of the enemy's fire destruction by rocket forces and artillery was developed.

Keywords: efficiency, the functioning of the artillery reconnaissance system, the enemy's fire destruction by rocket forces and artillery, the system of mass service, the flow of applications, the intensity of receipt of applications for obtaining intelligence data. 